\title{
PEMBERDAYAAN PEREKONOMIAN MASYARAKAT MELALUI KOPERASI UNIT DESA BERBASIS USAHA TERBIMBING
}

\author{
Erlina Rufaidah \\ Universitas Lampung
}

Jalan Sumantri Brojonegoro No. 01, Gedong Meneng, 35141, Bandar Lampung

E-mail: erlinarufaidah1958@gmail.com

\begin{tabular}{c|c|c}
\hline Received: & Revised: & $\begin{array}{c}\text { Approved: } \\
05 / 12 / 2017\end{array}$ \\
$17 / 08 / 2017$ & $28 / 11 / 2017$ & \\
\hline & CC (†) (O)
\end{tabular}

Pemberdayaan Perekonomian Masyarakat Melalui Koperasi Unit Desa

Berbasis Usaha Terbimbing is licensed under a Creative Commons

Attribution-ShareAlike 4.0 International License.

\begin{abstract}
Abstrak
Koperasi dan masyarakat merupakan aspek penting dalam peningkatan ekonomi pedesaan yang akan bermuara pada kemajuan desa tersebut. Maka koperasi dan masyarakat tidak dapat berjalan sendiri-sendiri atau bergerak terlalu dominan pada salah satu aspek nya, sehingga pola gerakan koperasi harus selalu beriringan dengan pola gerakan masyarakat sebagai anggotanya. Usaha terbimbing merupakan sebuah perlakuan khusus kepada pelaku usaha untuk dapat diberikan pendampingan, pembimbingan, penyuluhan hingga pada tahap evaluasi usaha. Hal tersebut dimaksudkan agar pelaku usaha tersebut dapat terarah dengan baik, mampu memecahkan masalah, mampu menjawab tantangan, mampu mengikuti perkembangan zaman dan memiliki daya saing sehingga usaha yang didirikan dapat terus maju dan berkembang sebagai bukti turut ambil bagian dalam pembangunan perekonomian masyarakat. Pemberdayaan dengan cara pembimbingan atau pendampingan dinilai akan berjalan lebih efektif dan efesien sehingga target yang telah ditentukan dapat lebih mudah dicapai. Paradigma yang masih menganggap koperasi menjadi jalan untuk kepentingan individual
\end{abstract}


profit oriented sudah seharusnya untuk di-revitalisasi menjadi multi-purpose oriented. Sehingga fungsi dan peran koperasi dapat berjalan dengan optimal sesuai dengan prinsip-prinsipnya. Pengembangan model usaha terbimbing dipandang akan menjadi jalan solusi bagi koperasi unit desa untuk dapat mencapai target capaian yang telah ditetapkan.

Kata kunci: Pemberdayaan Perekonomian, Koperasi Unit Desa, dan Usaha Terbimbing

\section{Abstract}

Cooperation and community is the important aspect in increasing rural economic which lead to the development of its rural area. Then, cooperation and community can not walk aone or moving dominanly on one of the aspect, so the cooperation pattern movement must be hand in hand with community pattern movement as its member. Guided business is a special treatment to the businessmen in order to get guiding, supervising, counseling until evaluation business step. That means the businessmen will be guided well, able to solve problem, able to answer the challenge, able following development era and have competitiveness so the business that established able to develop, As proof of taking part in community economical development. Empowerment by way of mentoring or mentoring assessed will run more effectively and efficiently so that the target that has been determined can be more easily achieved. The paradigm that still considers the cooperative to be the way for the benefit of individual profit oriented is supposed to be in the revitalization become multi-purpose oriented. So, the function and role of cooperation can run optimally in accordance with the principles. The development of a guided business model is seen as the path of solution for the cooperation of village unit (KUD) to achieve the established performance target.

Keyword: Economical Empowering, The Cooperation of Village Unit (KUD), and Guided Business

\section{A. Pendahuluan}

Pemikiran untuk mewujudkan sistem ekonomi yang berasaskan kekeluargaan telah lama dicita-citakan oleh bangsa Indonesia untuk menggantikan secara fundamental sistem kapitalis yang dilaksanakan kolonialis ${ }^{1}$. Sesuai dengan Peraturan Kepala BPS Nomor 66 Tahun 2016 bahwa jumlah desa/kelurahan di Indonesia

${ }^{1}$ Nasution, M. 1990. Keragaan Koperasi Unit Desa Sebagai Organisasi Ekonomi Pedesaan. Disertasi. Fakultas Pasca Sarjana. Institut Pertanian Bogor. Bogor. 
berjumlah 82.038. Melihat besarnya jumlah desa yang ada di Indonesia maka hal tersebut semestinya mampu dijadikan sumber potensi pergerakan perekonomian yang berasal dari pemberdayaan masyarakat pedesaan. Salah satu yang menjadi lokomotor penggerak perekonomian pedesaan yaitu koperasi unit desa. Istilah koperasi unit desa bukan merupakan hal yang baru di Indonesia, hal tersebut dikarenakan lembaga tersebut memiliki fungsi dan peran strategis sebagai perpanjangan tangan pemerintah dalam hal pembangunan ekonomi kerakyatan khususnya di pedesaan. Fungsi dan peran strategis tersebut menuntut adanya peningkatan taraf hidup manusia dan masyarakat sebagai bagian dari anggotanya.

Dalam Undang-undang perkoperasian No. 25 tahun 1992 dijelaskan bahwa peran dan fungsi koperasi adalah (1) membangun dan mengembangkan potensi dan kemampuan ekonomi anggota pada khususnya dan masyarakat pada umumnya untuk meningkatkan kesejahteraan ekonomi dan sosialnya, (2) berperan serta secara aktif dalam upaya mempertinggi kualitas kehidupan manusia dan masyarakat, (3) memperkokoh perekonomian rakyat sebagai dasar kekuatan dan ketahanan perekonomian nasional dengan Koperasi sebagai soko gurunya, (4) berusaha untuk mewujudkan dan mengembangkan perekonomian nasional yang merupakan usaha bersama berdasar atas asas kekeluargaan dan demokrasi ekonomi.

Koperasi dan masyarakat merupakan aspek penting dalam peningkatan ekonomi pedesaan yang akan bermuara pada kemajuan desa tersebut. Maka koperasi dan masyarakat tidak dapat berjalan sendiri-sendiri atau bergerak terlalu dominan pada salah satu aspek nya, sehingga pola gerakan koperasi harus selalu beriringan dengan pola gerakan masyarakat sebagai anggotanya.

Sebagai organisasi yang berasaskan kekeluargaan koperasi harus dapat menjadi jembatan penyampaian aspirasi dan ide kreatif masyarakat dalam rangka tercapainya peningkatan taraf hidup. Selain itu juga koperasi diharapkan menjadi sokoguru perekonomian nasional yang mampu untuk mengembangkan ekonomi bukan hanya pada taraf yang makro, tetapi juga pada taraf ekonomi mikro melalui pemberdayaan masyarakat pedesaan melalui kegiatan koperasi unit desa. 
Penelitian terkait dengan pemberdayaan masyarakat melalui koperasi yang sudah dipublikasikan diantaranya, Ravik $(2007)^{2}$, Eddi $(2014)^{3}$, I Made $(2007)^{4}$. Beda penelitian ini terhadap hasil penelitian sebelumnya yang sudah dipublikasikan yaitu adanya upaya pendampingan dalam bentuk usaha terbimbing yang dijadikan sebagai basis penopang sekaligus pendorong agar fungsi dan peran koperasi unit desa dapat berjalan dengan optimal sehingga pemberdayaan perekonomian masyarakat dapat terpenuhi.

Pemberdayaan lebih dari sekedar menolong yang bersifat charity, namun lebih dari itu, yakni bagaimana masyarakat yang diberdayakan keluar menjadi masyarakat yang memiliki kemampuan untuk mengeksploitasi kemampuan diri pribadi dan orang lain dengan aktivitas sosial, ekonomi, politik, partisipasinya terhadap pembangunan ekonomi dan pembagunan strategis lainnya dalam kehidupan sosial, berbangsa, serta bernegara ${ }^{5}$.

Usaha terbimbing merupakan sebuah perlakuan khusus kepada pelaku usaha untuk dapat diberikan pendampingan, pembimbingan, penyuluhan hingga pada tahap evaluasi usaha. Hal tersebut dimaksudkan agar pelaku usaha tersebut dapat terarah dengan baik, mampu memecahkan masalah, mampu menjawab tantangan, mampu mengikuti perkembangan zaman dan memiliki daya saing sehingga usaha yang didirikan dapat terus maju dan berkembang sebagai bukti turut ambil bagian dalam pembangunan perekonomian masyarakat.

Pembangunan yang hanya mengutamakan pertumbuhan ekonomi yang terpusat dan tidak merata serta tidak diimbangi

${ }^{2}$ Ravik Kasidi, Pemberdayaan Masyarakat untuk Usaha Kecil dan Mikro (Pengalaman Empiris di Wilayah Surakarta Jawa Tengah), dalam Jurnal Penyuluhan, Vol 3, No 2, Tahun 2007.

${ }^{3}$ Eddi Indro Asmoro, Model Efektivitas Pemberdayaan Perekonomian Masyarakat dengan Peran Pemerintah Mengakomodasi Hobi/Minat dan Bakat Masyarakat, dalam Jurnal Dinamika Teknik Vol 30, No 1, Tahhun 2014, 17-25.

${ }^{4}$ I Made Marsa Arsana, Faktor-Faktor yang Berpengaruh terhadap Kinerja Keuangan Koperasi Unit Desa di Kabupaten Tabanan Suatu Pendekatan Structural Equation Modelling, dalam Jurnal SOCA (Socio-Economic of Agriculturre and Agribusiness), Vol 7, No 1, Tahun 2007.

${ }^{5}$ Nofrianto dan Suardi, Bank Syariah dan Pemberdayaan Coorporate Social Responsibility: Peran dan Fungsi Bank Syariah Perspektif Filosofi Sosio-Ekonomi, dalam Jurnal AKADEMIKA, Vol. 20, No. 02, Tahun 2015. 
kehidupan sosial, politik, ekonomi yang demokratis dan berkeadilan telah menghasilkan fundamental pembangunan ekonomi yang rapuh. Rapuhnya fondasi perekonomian nasional telah mengakibatkan Indonesia terjebak dalam krisis ekonomi yang berkepanjangan serta menurunnya daya saing ekonomi nasional ${ }^{6}$

Dengan demikian apabila usaha tersebut dapat berjalan sesuai dengan target capaiannya maka usaha tersebut akan mencapai titik optimal dan secara tidak langsung juga berdampak pada kemakmuran koperasi yang ada sehingga juga akan mampu memberikan manfaat kepada anggota masyarakat secara luas.

\section{B. Upaya Pemberdayaan Masyarakat Melalui Revitalisasi Koperasi Unit Desa}

Pemberdayaan (empowerment) berarti memberikan motivasi dan dorongan kepada masyarakat/ individu untuk menggali potensi yang dimiliki untuk kemudian ditingkatkan kualitasnya agar mampu tumbuh dan berkembang. ${ }^{7}$ Berkaitan dengan hal tersebut pemberdayaan masyarakat merupakan sebuah gerakan yang memberikan dorongan kepada masyarakat dengan tujuan agar dapat mengoptimalkan potensi diri sehingga dapat meningkatkan kualitas dan taraf hidup. Memberdayakan masyarakat adalah memampukan dan memandirikan masyarakat. Keberdayaan masyarakat adalah unsur dasar yang memungkinkan suatu masyarakat untuk bertahan, dan mengembangkan diri untuk mencapai kemajuan. ${ }^{8}$

Pemberdayaan masyarakat melalui kegiatan koperasi unit desa ialah salah satu bentuk treatment yang dilakukan oleh masyarakat pedesaan dalam rangka menggerakkan roda perekonomian keluarga secara khusus dan pedesaan pada umumnya. Sejalan dengan semangat koperasi adalah sebagai badan usaha yang beranggotakan orang-orang atau badan hukum koperasi dengan melandaskan

${ }^{6}$ Rencana Strategis Kementerian Koperasi dan UKM Periode Tahun $2005-2009$

7 Studio Driya Medina, Berbuat bersama berperan setara. Pengkajian dan perencaan program bersama masyarakat. Konsorsium pengembangan dataran tinggi Nusa Tenggara, (1994), 247.

8 Ayi Sobarna, Konsep Pemberdayaan Ekonomi Bagi Masyarakat Miskin Perkotaan, dalam Jurnal Mimbar, Vol 19, No 3, Tahun 2003. 
kegiatannya berdasarkan prinsip koperasi sekaligus sebagai gerakan ekonomi rakyat yang berdasarkan atas asas kekeluargaan. ${ }^{9}$

Model perekonomian koperasi sebenarnya sudah cukup lama berkembang di masyarakat khususnya koperasi unit desa, kendati demikian pengelolaan yang dilakukan masih kurang optimal. Sebenarnya koperasi memiliki potensi kekuatan yang bersumber dari sektor sumber daya manusia (anggotanya) namun apabila potensi tersebut tidak terarahkan atau bahkan sampai terabaikan maka koperasi tersebut sulit untuk dapat berkembang secara signifikan. Selain itu juga yang kemudian menjadi alasan mendasar mengapa koperasi pada masyarakat pedesaan sulit berkembang yaitu disebabkan oleh pengaruh tingkat pengetahuan masyarakat tentang dunia perkoperasian yang masih kurang, akses informasi yang masih terbatas, dan sistem pembagian hasil yang belum termanajemen dengan baik, terlebih sikap individual profit oriented dalam usaha dari masing-masing anggota menjadi faktor penyebabnya. Kondisi yang hampir dialami oleh setiap koperasi unit desa menandakan perlu dilakukannya sebuah revitalisasi koperasi unit desa sebagai upaya pemberdayaan masyarakat agar dapat berjalan optimal.

Revitalisasi koperasi dapat tercapai dengan baik apabila anggota masyarakat yang terlibat didalamnya telah secara otomatis ikut direvitalisasi. Masyarakat sebagai bagian penting dalam koperasi diharapkan mampu meningkatkan perekonomian melalui ketersediaan sumber daya manusia yang memiliki softskill dan jiwa wirakoperasi dalam mengelola koperasi unit desa.

Pemberdayaan dan peningkatan peran dan fungsi masyarakat dalam pengembangan koperasi unit desa dapat dilakukan dengan cara memberikan suatu dorongan kepada masyarakat untuk dapat mengembangkan usaha sebagai bentuk kemandirian ekonomi dan memberikan penyuluhan kepada koperasi unit desa dalam hal pengembangan dan fungsinya. Masyarakat yang mandiri dalam ekonomi dan memiliki tingkat kepedulian sosial yang tinggi merupakan tujuan lahirnya koperasi. Potensi wilayah yang berlimpah dapat dimanfaatkan secara optimal dengan adanya kerjasama yang kontinu

${ }^{9}$ Undang-undang tentang perekonomian UU No 25 tahun 1992 Lembaran Negara RI tahun 1992 No 116 pasal 1 ayat (1). 
dari masyarakat sebagai pengelola sumberdaya dan pelaku koperasi untuk mencukupi kebutuhan sosial dan ekonomi masyarakat.

Secara konseptual pemberdayaan perekonomian melalui koperasi unit desa terutama dapat dilakukan dengan sistem pemberdayaan pelaku usaha itu sendiri. Keberhasilan pemberdayaan sangat bergantung pada partisipasi anggota sebagai pelaku maupun stakeholder lain yang turut dalam pengembangannya. Dalam hal ini pola alur gerakannya lebih diupayakan dilakukan secara partisipatif kolektif.

Pemberdayaan ekonomi masyarakat adalah suatu usaha atau upaya dalam mensejahterakan kehidupan masyarakat dengan tujuan akhir untuk mengurangi tingkat pengangguran ${ }^{10}$. Konteks terkait kesejahteraan masyarakat, beberapa teori seperti teori ekonomi kesejahteraan, teori ekspektasi, teori motivasi, dan teori Y menjelaskan: (1) secara substansial, kesejahteraan masyarakat dipengaruhi oleh faktor eksternal seperti lingkungan yang ada di sekitar masyarakat miskin dan intervensi pemerintah dan beberapa faktor internal (faktor demografis) seperti tingkat pendidikan, kemampuan kerja, motivasi kerja, kinerja, pengalaman kerja, dan karakteristik individual; (2) perubahan kesejahteraan masyarakat ke arah lebih baik atau lebih tinggi merupakan tujuan utama dari implementasi program peningkatan kesejahteraan masyarakat. ${ }^{11}$

Upaya pemberdayaan koperasi unit desa dapat dilakukan melalui identifikasi dan analisis hubungan sebab akibat antara faktorfaktor penentu keberhasilan pada koperasi unit desa yang maju dan mandiri. Hasil kajian tersebut dapat dijadikan sebagai pedoman karena faktor-faktor tersebut mempunyai pengaruh langsung maupun tidak langsung pada tingkat keberhasilan koperasi unit desa. ${ }^{12}$

${ }^{10}$ Robiatul Auliyah, Pemberdayaan Ekonomi Masyarakat adalah suatu Usaha atau Upaya dalam Mensejahterakan Kehidupan Masyarakat dengan Tujuan Akhir untuk Mengurangi Tingkat Pengangguran, dalam Jurnal Studi Manajemen, Vol 8, No 1, Tahun 2014

11 Mochamad Ridwan, Penguatan Ekonomi Masyarakat Berbasis Kelompok dalam Jurnal Ekonomi Pembangunan, Vol 13, No 2, Tahun 2012.

12 Sulistyo Sidik Purnomo, Briljan Sudjana, Pemberdayaan Koperasi Unit Desa melalui Analisis Faktor-Faktor Manajemen, dalam Jurnal Agrikultura, Vo 21, No 1, Tahun 2010. 
Indonesia sebagai Negara berkembang telah memajukan dan menggerakkan koperasi sebagai salah satu badan usaha sekaligus gerakan ekonomi rakyat. Maka dari itu, koperasi harus berjalan sesuai dengan prinsip-prinsip koperasi yang merupakan landasan pokok dalam menjalankan usahanya. Prinsip-prinsip tersebut meliputi kemandirian, keanggotaan yang bersifat terbuka, pengelolaan yang dilakukan secara demokratis, pembagian sisa hasil usaha secara adil dansebanding dengan besarnya jasa usaha masing-masing anggota, pemberian balas jasa yang terbatas atas modal, pendidikan perkoperasian serta kerjasama antar koperasi. Prinsip-prinsip tersebut membedakan koperasi dengan badan usaha lain. ${ }^{13}$

Dengan demikian upaya pemberdayaan masyarakat melalui revitalisasi koperasi unit desa dipandang perlu dilakukan baik dari segi pemberdayaan, pelaksanaan, pengelolaan maupun pengawasan. Hal tersebut dilakukan agar koperasi unit desa dapat dijadikan wadah pengembangan kemampuan diri dan peningkatan perekonomian yang akan juga berdampak langsung pada peningkatan kualitas dan taraf hidup anggota dan masyarakat sekitar.

\section{Pemberdayaan Masyarakat Berbasis Pengembangan Model Usaha Terbimbing}

Rendahnya jumlah wirausaha yang dimiliki Indonesia tentunya akan berpengaruh terhadap tingkat pengangguran dan pendapatan perkapita, yang jika terus dibiarkan akan menghambat citacita bangsa Indonesia untuk mencapai kesejahteraan dan kemakmuran sebagaimana yang diamanatkan dalam pembukaan UUD'45. ${ }^{14}$

Model usaha terbimbing merupakan instrumen pengelolaan usaha yang terbilang jarang ditemui. Ide ini muncul berdasarkan pengalaman empiris selama ini yang melibatkan dua orang atau lebih sebagai bagian dari pengembangan dan pencapaian tujuan bersama. Hal tersebut terinspirasi dari pola pendidikan teman sejawat pada siswa di ruang kelas, maka dengan mengadopsi konsep yang sama 2000), 125.

13 Subrawardi K. Lubis, Hukum Ekonomi Islam (Jakarta: Sinar Grafika,

${ }_{14}$ Yudha Nata Saputra, Pengembangan Kurikulum Kewirausahaan di Sekolah Menengah Pertama, dalam Jurnal Pendidikan dan Kebudayaan, Vol. 17, No. 5, Tahun 2011. 
peneliti mencoba mengembangkannya di dunia usaha dengan melibatkan dua orang atau lebih pelaku usaha dimana mereka masih dalam satu produk usaha yang sejenis.

Pelaku usaha yang sudah lebih dahulu terjun di usaha tersebut bertanggungjawab untuk dapat membimbing pelaku usaha lain dengan memanfaatkan pengalaman yang telah didapat sebelumnya. Model ini dipandang sangat cocok bagi masyarakat pedesaan dimana secara kultur kehidupan masyarakat pedesaan masih sangat dominan rasa gotong royong dan semangat kekeluargaan yang terjalin.

Pemberdayaan dengan cara pembimbingan atau pendampingan dinilai akan berjalan lebih efektif dan efesien sehingga target yang telah ditentukan dapat lebih mudah dicapai. Hal tersebut didasarkan pada pola pembimbingan atau pendampingan akan selalu berusaha untuk dapat saling membantu satu sama lain dalam hal pemecahan masalah sehingga setiap permasalahan yang dihadapi akan dengan cepat dapat terselesaikan.

Untuk melakukan pemberdayaan masyarakat secara umum dapat diwujudkan dengan menerapkan prinsip-prinsip dasar pendampingan masyarakat (Karsidi, 1988) ${ }^{15}$, sebagai berikut:

\section{Belajar Dari Masyarakat}

Prinsip yang paling mendasar adalah prinsip bahwa untuk melakukan pemberdayaan masyarakat adalah dari, oleh, dan untuk masyarakat. Ini berarti, dibangun pada pengakuan serta kepercayaan akan nilai dan relevansi pengetahuan tradisional masyarakat serta kemampuan masyarakat untuk memecahkan masalahmasalah sendiri.

\section{Pendamping sebagai Fasilitator, Masyarakat sebagai Pelaku}

Konsekuensi dari prinsip pertama adalah perlunya pendamping menyadari perannya sebagai fasilitator dan bukannya sebagai pelaku atau guru. Untuk itu perlu sikap rendah hati serta kesediaan belajar dari masyarakat dan menempatkan warga masyarakat sebagai narasumber utama dalam memahami keadaan masyarakat itu sendiri. Bahkan dalam penerapannya masyarakat

${ }^{15}$ Karsidi, Ravik, Pengorganisasian Potensi Pembangunan Masyarakat, Suatu Model Menumbuhkan Partisipasi, Makalah, KNPI Surakarta, (1988). 
dibiarkan mendominasi kegiatan. Kalaupun pada awalnya peran pendamping lebih besar, harus diusahakan agar secara bertahap peran itu bisa berkurang dengan mengalihkan prakarsa kegiatankegiatan pada warga masyarakat itu sendiri.

\section{Saling Belajar, Saling Berbagi Pengalaman}

Salah satu prinsip pendampingan untuk pemberdayaan masyarakat adalah pengakuan akan pengalaman dan pengetahuan lokal masyarakat. Hal ini bukanlah berarti bahwa masyarakat selamanya benar dan harus dibiarkan tidak berubah. Kenyataan objektif telah membuktikan bahwa dalam banyak hal perkembangan pengalaman dan pengetahuan lokal (bahkan tradisional) masyarakat tidak sempat mengejar perubahan-perubahan yang terjadi dan tidak lagi dapat memecahkan masalah-masalah yang berkembang. Namun sebaliknya, telah terbukti pula bahwa pengetahuan modern dan inovasi dari luar yang diperkenalkan oleh orang luar tidak juga dapat memecahkan masalah mereka. Bahkan dalam banyak hal, pengetahuan modern dan inovasi dari luar malah menciptakan masalah yang lebih besar lagi. Karenanya pengetahuan lokal masyarakat dan pengetahuan dari luar atau inovasi, harus dipilih secara arif dan atau saling melengkapi satu sama lainnya.

Pemberdayaan ekonomi masyarakat adalah proses perolehan pelaku ekonomi untuk mendapatkan surplus value sebagai hak manusia yang terlibat dalam kegiatan produksi ${ }^{16}$.

Indikator yang menjadi tolak ukur keberhasilan model usaha terbimbing pada koperasi unit desa ditentukan berdasarkan penilaian keterbutuahan dan aspek strategis dari masing-masing faktor. Berdasarkan hasil analisis faktor pendukung yang terdiri dari sumber daya manusia, sarana dan prasarana, aspek penunjang dan evaluasi diperoleh bahwa indikator dari masing-masing faktor pendukung dapat tercapai melalui model usaha terbimbing, atau dengan kata lain koperasi unit desa ini adalah lembaga ekonomi yang multi-purpose yakni tidak hanya mencari keuntungan financial tetapi

${ }^{16}$ P. Eko Prasetyo dan Siti Maisaroh, Model strategi pemberdayaan ekonomi rakyat sebagai upaya pengentasan kemiskinan, dalam Jurnal Trinomika, Vol 8, No 2, Tahun 2009. 
juga bertujuan untuk meningkatkan kemampuan dan kesejahteraan para anggotanya.

\section{Simpulan}

Pemberdayaan ekonomi masyarakat merupakan sebuah tantangan yang cukup besar namun hadirnya koperasi unit desa dinilai mampu menjadi jawaban atas tantangan tersebut. Koperasi sebagai bagian yang tidak dapat dipisahkan dari masyarakat sudah semestinya kembali dijadikan sebagai pijakan awal penggerak perekonomian masyarakat. Prinsip-prinsip koperasi sebagai wadah bagi masyarakat untuk dapat terberdayakan harusnya terus dijaga dan diinternalisasi melalui berbagai kegiatan-kegiatannya.

Paradigma yang masih menganggap koperasi menjadi jalan untuk kepentingan individual profit oriented sudah seharusnya untuk di-revitalisasi menjadi multi-purpose oriented. Sehingga fungsi dan peran koperasi dapat berjalan dengan optimal sesuai dengan prinsipprinsipnya. Pengembangan model usaha terbimbing dipandang akan menjadi jalan solusi bagi koperasi unit desa untuk dapat mencapai target capaian yang telah ditetapkan.

Model usaha terbimbing sebagai jalan pemberdayaan masyarakat hendaknya mengacu pada prinsip-prinsip dasar pendampingan masyarakat, yaitu: belajar dari masyarakat, pendamping sebagai fasilitator dan dapat tercipta saling belajar dan berbagi pengalaman. Dengan demikian para pelaku dapat mencapai multi-purpose oriented yakni mendapatkan keuntungan secara financial dan juga dapat terus mengeksplorasi potensi diri untuk lebih terarah guna meningkatkan perekonomian, taraf hidup, dan kesejahteraan masyarakat[.] 


\section{REFERENSI}

Ayi Sobarna, Konsep Pemberdayaan Ekonomi Bagi Masyarakat Miskin Perkotaan, dalam Jurnal Mimbar, Vol 19, No 3, Tahun 2003.

Eddi Indro Asmoro, Model Efektivitas Pemberdayaan Perekonomian Masyarakat dengan Peran Pemerintah Mengakomodasi Hobi/Minat dan Bakat Masyarakat, dalam Jurnal Dinamika Teknik Vol 30, No 1, Tahhun 2014, h 17-25.

I Made Marsa Arsana, Faktor-Faktor yang Berpengaruh terhadap Kinerja Keuangan Koperasi Unit Desa Di Kabupaten Tabanan Suatu Pendekatan Structural Equation Modelling, dalam Jurnal SOCA (Socio-Economic of Agriculturre And Agribusiness), Vol 7, No 1, Tahun 2007.

Karsidi, Ravik, Pengorganisasian Potensi Pembangunan Masyarakat, Suatu Model Menumbuhkan Partisipasi, Makalah, KNPI Surakarta, (1988).

Mochamad Ridwan, Penguatan Ekonomi Masyarakat Berbasis Kelompok dalam Jurnal Ekonomi Pembangunan, Vol 13, No 2, Tahun 2012.

Nasution, M. 1990. Keragaan Koperasi Unit Desa Sebagai Organisasi Ekonomi Pedesaan. Disertasi. Fakultas Pasca Sarjana. Institut Pertanian Bogor. Bogor.

Nofrianto dan Suardi, Bank Syariah dan Pemberdayaan Coorporate Social Responsibility: Peran dan Fungsi Bank Syariah Perspektif Filosofi Sosio-Ekonomi, dalam Jurnal AKADEMIKA, Vol. 20, No. 02, Tahun 2015.

P. Eko Prasetyo dan Siti Maisaroh, Model Strategi Pemberdayaan Ekonomi Rakyat sebagai Upaya Pengentasan Kemiskinan, dalam Jurnal Trinomika, Vol 8, No 2, Tahun 2009.

Ravik Kasidi, Pemberdayaan Masyarakat Untuk Usaha Kecil dan Mikro (Pengalaman Empiris di Wilayah Surakarta Jawa Tengah), dalam Jurnal Penyuluhan, Vol 3, No 2, Tahun 2007.

Rencana Strategis Kementerian Koperasi dan UKM Periode Tahun $2005-2009$. 
Robiatul Auliyah, Pemberdayaan Ekonomi Masyarakat adalah suatu Usaha atau Upaya dalam Mensejahterakan Kehidupan Masyarakat dengan Tujuan Akhir Untuk Mengurangi Tingkat Pengangguran, dalam Jurnal Studi Manajemen, Vol 8, No 1, Tahun 2014.

Studio Driya Medina, Berbuat Bersama Berperan Setara. Pengkajian dan Perencaan Program Bersama Masyarakat. Konsorsium Pengembangan Dataran Tinggi Nusa Tenggara, (1994), h 247.

Subrawardi K. Lubis, Hukum Ekonomi Islam (Jakarta: Sinar Grafika, 2000), h 125.

Sulistyo Sidik Purnomo, Briljan Sudjana, Pemberdayaan Koperasi Unit Desa melalui Analisis Faktor-Faktor Manajemen, dalam Jurnal Agrikultura, Vo 21, No 1, Tahun 2010.

Undang-Undang Tentang Perekonomian UU No 25 Tahun 1992 Lembaran Negara RI Tahun 1992 No 116 Pasal 1 Ayat (1).

Yudha Nata Saputra, Pengembangan Kurikulum Kewirausahaan di Sekolah Menengah Pertama, dalam Jurnal Pendidikan dan Kebudayaan, Vol. 17, No. 5, Tahun 2011. 
